\title{
Sistem Pendukung Keputusan Dalam Menentukan Aparatur Sipil Negara Terbaik Pada Kantor Camat Siantar Utara Dengan Metode ELECTRE
}

\author{
Notryady Purba ${ }^{1}$, Dedy Hartama ${ }^{2}$, Jalaluddin ${ }^{3}$, Solikhun ${ }^{4}$, Fitri Anggraini ${ }^{5}$ \\ ${ }^{1}$ Mahasiswa Program Studi Teknik Informatika, STIKOM Tunas Bangsa. \\ Pematangsiantar, Sumatera Utara, Indonesia \\ ${ }^{2,3,5}$ STIKOM Tunas Bangsa, Pematangsiantar, Sumatera Utara, Indonesia \\ ${ }^{4}$ AMIK Tunas Bangsa, Pematangsiantar, Sumatera Utara, Indonesia \\ notryady_purba@yahoo.co.id
}

\begin{abstract}
Siantar Utara District Office is one of the sub-districts in the Pematangsiantar city, North Sumatra Province. Through this sub-district office, residents can take care of various forms of licensing. At the subdistrict office also routinely held awards to employees which are held every three months which were previously counted on the excel application. The calculation process determines the best employee that the writer does, namely with the Excel application and uses the web-based ELECTRE method. Based on the final results obtained from the calculation results in both the excel application and the web-based application, alternative $A_{1}$ with $E_{k l}=4$ value, alternative $A_{2}$ with $E_{k l}=4$ value, alternative $A_{3}$ with $E_{k l}=0$ value, alternative $A_{4}$ with $E_{k l}=2$ value, alternative $A_{5}$ with the value $E_{k}=2$ From this decision support system, the final result is obtained with alternative Al with the value $E_{k l}=4$ as the best employee.
\end{abstract}

Keywords: Decision Support System, State Civil Apparatus, ELECTRE.

\begin{abstract}
Abstrak
Kantor Camat Siantar Utara merupakan salah satu kecamatan yang ada di kota pematangsiantar, Provinsi Sumatera Utara. Melalui kantor camat ini warga dapat mengurus berbagai bentuk perizinan. Pada kantor camat tersebut juga rutin dilaksanakan pemberian penghargaan kepada pegawainya yang dilaksanakan setiap tiga bulan sekali yang sebelumnya dihitung pada aplikasi excel. Adapun proses perhitungan menentukan pegawai terbaik yang penulis lakukan yaitu dengan aplikasi excel dan menggunakan metode ELECTRE berbasis web. Berdasarkan hasil akhir yang diperoleh dari hasil perhitungan baik pada aplikasi excel maupun aplikasi berbasis web, maka didapat alternatif $A_{1}$ dengan nilai $E_{k l}=4$, alternatif $A_{2}$ dengan nilai $E_{k l}=4$, alternatif $A_{3}$ dengan nilai $\mathrm{E}_{\mathrm{kl}}=0$, alternatif $\mathrm{A}_{4}$ dengan nilai $\mathrm{E}_{\mathrm{kl}}=2$, alternatif $\mathrm{A}_{5}$ dengan nilai $\mathrm{E}_{\mathrm{kl}}=2$ Dari sistem pendukung keputusan ini diperoleh hasil akhir dengan alternatif $\mathrm{A}_{1}$ dengan dengan nilai $\mathrm{E}_{\mathrm{kl}}=4$ sebagai pegawai terbaik.
\end{abstract}

Kata kunci: Sistem Pendukung Keputusan, Aparatur Sipil Negara, ELECTRE.

\section{Pendahuluan}

Setiap organisasi maupun perkantoran membutuhkan sumber daya manusia yang mampu bekerja secara optimal dalam mencapai tujuan organisasi. Penilaian prestasi kerja adalah proses dimana pemimpin menilai kemajuan yang dicapai pegawai kearah sasaran yang ditetapkan. Keterlibatan kerja merupakan ukuran sejauh mana individu terlibat dalam pekerjaannya. Motivasi kerja adalah dorongan supaya pegawai giat dan antusias dalam mencapai hasil optimal. Kepuasan kerja adalah rasa aman pegawai terhadap pekerjaannya (Gladys, 2013). Era globalisasi saat ini Sumber Daya Manusia merupakan aspek penting dalam pencapaian suatu tujuan. Setiap organisasi atau perusahaan menjamin dipilihnya sumber daya manusia yang 
tepat dengan pekerjaan serta kondisi yang memungkinkan mereka bekerja optimal (Darmawan, 2013:3). Untuk itu Kantor Camat Siantar Utara selalu berusaha untuk meningkatkan kepuasan kerja pegawai agar supaya pegawai dapat meningkatkan kinerja mereka dengan hasil kepuasan yang dirasakan.

Pada penelitian ini, penulis akan menetukan prestasi terbaik dengan menerapkan metode ELECTRE untuk menentukan prestasi Aparatur Sipil Negara terbaik di Kantor Camat siantar Utara. Data yang digunakan penulis diperoleh dari Arsip Kantor Camat Siantar Utara. Adapun kriteria data yang digunakan yaitu kehadiran, kinerja, tepat waktu. Pengukuran terhadap tingkat kepuasan kerja pegawai, penilaian prestasi kerja sangat penting dilakukan secara objektif kepada setiap pegawai. Penilaian prestasi kerja merupakan suatu proses yang melibatkan pemimpin dan pegawai, dimana pemimpin menilai kemajuan yang telah dicapai pegawai kearah sasaran yang telah ditetapkan dalam perencanaan. Keterlibatan kerja juga sangat penting dalam pencapaian tujuan. Keterlibatan kerja merupakan derajat sejauh mana seseorang memihak secara psikologis terhadap pekerjaannya. Tingkat keterlibatan pegawai sangat dipengaruhi oleh besarnya tingkat kepuasan kerja yang dirasakannya. Kedua hal tersebut harus sejalan dengan pemberian motivasi kerja yang diberikan kepada pegawai. Motivasi kerja adalah hal yang menyebabkan seseorang supaya mau bekerja giat dan antusias mencapai hasil kerja yang optimal. Sistem Pendukung Keputusan (SPK) adalah salah satu cara mengorganisir informasi yang dimaksudkan untuk digunakan dalam membuat keputusan" [1]. Ada yang mendefinisikan bahwa system pendukung keputusan merupakan suatu pendekatan untuk mendukung pengambilan keputusan. Sistem pendukung keputusan menggunakan data, memberikan antarmuka pengguna yang mudah dan dapat menggabungkan pemikiran pengambil keputusan. Menurut [2]"ELECTRE merupakan salah satu metode pengambilan keputusan multikriteria berdasarkan pada konsep Outranking dengan menggunakan perbandingan berpasangan dari alternatif-alternatif berdasarkan setiap kriteria yang sesuai".

Metode ELECTRE digunakan pada kondisi dimana alternatif yang kurang sesuai dengan kriteria dieliminasi, dan alternatif yang sesuai dapat dihasilkan. Dengan kata lain, ELECTRE digunakan untuk kasus-kasus dengan banyak alternatif namun hanya sedikit kriteria yang dilibatkan. Suatu alternatif dikatakan mendominasi alternatif yang lainnya jika satuatau lebih kriterianya melebihi (dibandingkan dengan kriteria dari alternatif yang lain) dan sama dengan kriteria lain yang tersisa [3]. Adapun masalah dalam penelitian ini yaitu pada kantor camat tersebut selalu diadakan penentuan pegawai terbaik untuk pertiga bulannya. Namun pada penentuan pegawai terbaiknya dilakukan menggunaan aplikasi microsoft excel dan memakan waktu yang cukup lama. Tujuan penelitian yang di lakukan penulis dengan menggunakan Sistem Pendukung Keputusan ini diharapkan dapat memberikan kemudahan dalam menentukan pegawai yang berprestasi di Kecamatan Siantar Utara serta dapat meningkatkan aspek yang mendukung kinerja setiap pegawai di kantor tersebut. Dari permasalahan tersebut, maka penulis ingin mengangkat sebuah judul yaitu Sistem Pendukung Keputusan Dalam Menentukan Aparatur Sipil Negara Terbaik Pada Kantor Camat Siantar Utara Dengan Metode Elimination Et Choix Traduisant La Reality (ELECTRE).

\section{Metode Penelitian}

\subsection{Sistem Pendukung Keputusan}

Sistem pendukung keputusan merupakan sistem informasi interaktif yang menyediakan informasi, pemodelan, dan pemanipulasian data [3]. Sistem pendukung keputusan merupakan resources individu secara intelek dengan kemampuan komputer guna meningkatkan kualitasi keputusan dan bisa sebagai manajemen pengambilan keputusan [4]. Sistem pendukung keputusan ditujukan untuk 
pengambilan keputusan yang bersifat analistis dalam situasi yang tidak terstruktur dan dengan kriteria yang kurang jelas.

\subsection{Aparatur Sipil Negara (ASN)}

Aparatur Sipil Negara yang biasa disingkat ASN adalah profesi bagi Pegawai Negeri Sipil dan pegawai pemerintah dengan perjanjian kerja yang bekerja pada instansi pemerintahan.

\subsection{Algoritma Elimination Et Choix Traduisant La Realite (ELECTRE)}

ELECTRE merupakan salah satu metode pengambilan keputusan yang multikriteria berdasarkan pada konsep outranking dengan menggunakan perbandingan berpasangan dari alternatif-alternatif berdasarkan setiap kriteria yang sesuai. Metode ELECTRE digunakan pada kondisi dimana alternatif yang kurang sesuai dengan kriteria akan dieliminasi, dan alternatif yang sesuai dapat dihasilkan, dengan kata lain ELECTRE digunakan untuk kasus-kasus dengan banyak alternatif. Namun, hanya sedikit kriteria yang dilibatkan. Suatu alternatif dikatakan mendominasi alternatif yang lainnya jika satu atau lebih kriterianya melebihi (dibandingkan dengan kriteria dari alternatif yang lain) dan sama dengan kriteria lain yang tersisa [2][1][7].

\section{Hasil Pembahasan}

Penulis menggunakan data beberapa pegawai yang diperoleh dari Kantor Camat Siantar Utara Jln. Patuan Anggi untuk kemudian dibandingkan dengan data pegawai lainnya. Penulis terlebih dahulu menentukan kriteria-kriteria yang akan dijadikan acuan dalam pengambilan keputusan dan memberikan bobot penilaian untuk setiap kriteria.

Setelah menentukan kriteria,penulis melakukan penyusunan kriteria berdasarkan nilai perioritas. Mulai dari kriteria dengan nilai bobot terendah hingga kriteria dengan nilai bobot tertinggi. Rating kecocokan setiap alternatif pada setiap kriteria berbeda tergantung dari kriteria yang digunakan.

Tabel 1. Tingkat Kepentingan

\begin{tabular}{cl}
\hline Nilai & \multicolumn{1}{c}{ Keterangan } \\
\hline $1-3$ & Cukup \\
$4-6$ & Baik \\
$7-9$ & Sangat Baik \\
\hline
\end{tabular}

Berdasarkan kriteria dan rating kecocokan setiap alternatif yang telah ditentukan, selanjutnya akan diberikan nilai / bobot setiap alternatif pada setiap kriteria yang telah ditentukan. Berdasarkan nilai yang telah ditentukan pada setiap kriteria, penulis menentukan bobot untuk setiap alternatif yaitu 2, 3, 5, dimana 2 sebagai bobot terrendah dan 5 sebagai bobot tertinggi. Adapun bobot untuk setiap kriteria dapat dilihat pada tabel berikut:

Tabel 2. Kriteria dan Bobot

\begin{tabular}{cclc}
\hline No & & \multicolumn{1}{c}{ Kriteria } & Bobot \\
\hline 1 & $\mathrm{C}_{1}$ & Kehadiran & 2 \\
2 & $\mathrm{C}_{2}$ & Kinerja & 3 \\
3 & $\mathrm{C}_{3}$ & Tepat Waktu & 5 \\
\hline
\end{tabular}

Setelah menentukan pembobotan dan tingkat kepentingan, maka penulis menentukan alternatif yang akan diseleksi. Penulis mengambil 5 nama pegawai sebagai contoh yang akan dirating menurut kriteria yang dimiliki menggunakan metode ELECTRE. Setelah data alternatif diketahui, maka selanjutnya dilakukan penilaian untuk setiap alternatif sesuai dengan kriteria seperti pada tabel 3 berikut: 
Tabel 3. Tabel Penilaian Alternatif

\begin{tabular}{lccc}
\hline \multicolumn{1}{c}{ Alternatif } & \multicolumn{3}{c}{ Kriteria } \\
\cline { 2 - 4 } & Kehadiran & Kinerja & Tepat Waktu \\
\hline Mulatua Siregar & 50 & 15 & 08.00 \\
Mangaraja Tua Nababan & 40 & 16 & 08.31 \\
Missiadi & 40 & 8 & 09.00 \\
Lisna H Pohan & 30 & 16 & 09.00 \\
Erni Sari & 40 & 15 & 08.31 \\
\hline
\end{tabular}

Selanjutnya untuk dapat melakukan perhitungan dengan metode yang telah ditentukan maka nilai kriteria dari setiap alternatif yang masih dalam bentuk skala terlebih dahulu dikonversikan menjadi bentuk angka seperti pada tabel berikut:

Tabel 4. Konversi Penilaian Alternatif

\begin{tabular}{lccc}
\hline \multicolumn{1}{c}{ Alternatif } & \multicolumn{3}{c}{ Kriteria } \\
\cline { 2 - 4 } & Kehadiran & Kinerja & Tepat Waktu \\
\hline Mulatua Siregar & 7 & 6 & 9 \\
Mangaraja Tua Nababan & 6 & 7 & 6 \\
Missiadi & 6 & 4 & 4 \\
Lisna H Pohan & 4 & 7 & 3 \\
Erni Sari & 6 & 6 & 6 \\
\hline
\end{tabular}

Langkah-langkah perhitungan dengan menggunakan metode ELECTRE adalah sebagai berikut :

1) Menentukan Matriks Keputusan.

Matriks keputusan ditentukan dari tabel sebelumnya yang kemudian disusun kedalam matriks keputusan sebagai berikut:

$$
x_{i j=}\left[\begin{array}{lll}
7 & 6 & 9 \\
6 & 7 & 6 \\
6 & 4 & 4 \\
4 & 7 & 3 \\
6 & 6 & 6
\end{array}\right]
$$

2) Normalisasi Matriks Keputusan

Membuat normalisasi matriks keputusan sebagai berikut:

$\left|\mathrm{x}_{1}\right|=\sqrt{7^{2}+6^{2}+6^{2}+4^{2}+6^{2}}=\sqrt{173}=13,1520$

$\mathrm{r}_{11}=\frac{x_{11}}{\left|x_{1}\right|}=\frac{7}{13,1520}=0,5322$

$\mathrm{r}_{21}=\frac{x_{21}}{\left|x_{1}\right|}=\frac{6}{13,1520}=0,4562$

$\mathrm{r}_{31}=\frac{x_{31}}{\left|x_{1}\right|}=\frac{6}{13,1520}=0,4562$

$\mathrm{r}_{41}=\frac{x_{41}}{\left|x_{1}\right|}=\frac{4}{13,1520}=0,3041$

$\mathrm{r}_{51}=\frac{x_{51}}{\left|x_{1}\right|}=\frac{6}{13,1520}=0,4562$

Sehingga didapat matriks R sebagai berikut:

$$
r_{i j}=\left[\begin{array}{lll}
0,5322 & 0,4399 & 0,6746 \\
0,4562 & 0,5133 & 0,4497 \\
0,4562 & 0,2933 & 0,2998
\end{array}\right]
$$




$$
\text { Lemand }
$$

3) Pembobotan pada matriks yang telah dinormalisasi

Langkah selanjutnya yaitu dengan mengalikan matriks $\mathrm{R}$ dengan bobot setiap kriteria dengan persamaan $v i j=w_{i} r_{i j}$

Matriks $v$ dihitung sebagai berikut:

$$
\begin{aligned}
& v_{11}=2 * 0,5322=1,9644 \\
& v_{21}=2 * 0,4562=0,9123
\end{aligned}
$$

Setelah semua dihitung maka didapat hasil:

$$
v_{i j=}=\left[\begin{array}{lll}
1,9644 & 1,3198 & 3,3729 \\
0,9123 & 1,5398 & 2,2486 \\
0,9123 & 0,8799 & 1,4991 \\
0,6082 & 1,5398 & 1,1243 \\
0,9123 & 1,3198 & 2,2486
\end{array}\right]
$$

4) Menentukan himpunan Concordance dan Discordance

Himpunan concordance $\left\{\mathrm{C}_{\mathrm{kl}}\right\}$ menyatakan bahwa hitungan kriteria bobot $\mathrm{A}_{\mathrm{k}}$ dengan kemungkinan lain lebih baik daripada $\mathrm{A}_{\mathrm{l}}$.

$$
\begin{aligned}
& C_{k l}=\left\{j \mid v_{k j} \geq V_{l j}\right\} \text { dengan } \mathrm{j}=1,2, \ldots, \mathrm{n} . \\
& C_{21} \\
& \text { If } j=1 \rightarrow v_{21} \geq \mathrm{v}_{11} \rightarrow 0,9123 \geq 1,9644 \rightarrow=\text { no } \\
& \text { If } j=2 \rightarrow \mathrm{v}_{22} \geq \mathrm{v}_{12} \rightarrow 1,5398 \geq 1,3198 \rightarrow \text { yes then } j=2 \\
& \text { If } j=3 \rightarrow \mathrm{v}_{23} \geq \mathrm{v}_{13} \rightarrow 2,3094 \geq 3,3729 \rightarrow=\text { no } \\
& \text { Hasil } \mathrm{C}_{21}=\{2\}
\end{aligned}
$$

5) Menghitung Matriks Concordance dan Discordance

Untuk mengitung matriks concordance adalah dengan cara menambah bobot yang terdapat pada matriks concordance.

$$
c_{k l}=\sum_{j \in c_{k l}} W_{j}
$$

Hasil perhitungan diatas disusun menjadi sebuah matriks concordance sebagai berikut:

$$
C_{k l}=\left[\begin{array}{ccccc}
- & 2 & 0 & 2 & 2 \\
8 & - & 3 & 2 & 8 \\
10 & 10 & - & 2 & 10 \\
8 & 10 & 8 & - & 8 \\
10 & 10 & 3 & 2 & -
\end{array}\right]
$$

Untuk menentukan matriks discordance adalah dengan membagi selisih maksimum kriteria yang dimasukkan kedalam himpunan discordance dengan selisih tertinggi diantara nilai nilai yang ada pada semua kriteria.

$$
D_{k l}=\frac{\max \left\{\left|V_{k j}-V_{l j}\right|\right\}_{j \in D_{k I}}}{\max \left\{\left|V_{k j}-V_{l j}\right|\right\} \quad V_{j}}
$$

Hasil perhitungan diatas disusun kedalam sebuah matriks discordance berikut ini: 


$$
d_{i j}=\left[\begin{array}{ccccc}
- & 1 & 1 & 1 & 1 \\
0,1304 & - & 1 & 1 & 1 \\
0 & 0 & - & 1 & 0 \\
0,0652 & 0 & 0,9644 & - & 0,1304 \\
0 & 0 & 1 & 1 & -
\end{array}\right]
$$

6) Menentukan matriks concordane dominaan dan matriks discordance dominan.

Aray ini dapat membentuk nilai ambang atas (threshold) $\underline{C}$. Rumus yang dapat menghasilkan nilai $\mathrm{C}$ dan persamaan yang digunakan adalah persamaan 12 .

$$
\begin{aligned}
& \underline{c}=\frac{8+10+8+10+2+10+10+10+0+3+8+3+2+2+2+}{2+2+8+10+8} \\
& \underline{c}=\frac{118}{20}=5,9
\end{aligned}
$$

Sehingga elemen matriks $f$ ditentukan sebagai berikut.

$$
f_{k l}=0 \text {, jika } C_{k l} \geq \underline{C} \text { dan } f_{k l}=1 \text {, jika } C_{k l}<\underline{C}
$$

Sehingga matriks dominan concordance adalah

$$
f_{k l}=\left[\begin{array}{lllll}
- & 1 & 1 & 1 & 1 \\
0 & - & 1 & 1 & 0 \\
0 & 0 & - & 1 & 0 \\
0 & 0 & 0 & - & n \\
0 & 0 & 1 & 1 &
\end{array}\right]
$$

Hal yang sama dilakukan kepada matriks dominan discordance $\mathrm{G}$ dengan nilai ambang atas (threshold) $d$

$$
\begin{aligned}
& \underline{d}=\frac{0,1304+0+0,0652+0+1+0+0+0+1+1+0,9644+1+1+1+1+1+}{1+1+0+0,1304} \\
& \underline{d}=\frac{11,2904}{20} \\
& \underline{d}=0,5645
\end{aligned}
$$

Sehingga elemen matriks $\mathrm{G}$ ditentukan sebagai berikut:

$$
g_{k l}=1 \text {, jika } D_{k l} \geq \underline{d} \text { dan } g_{k l}=0 \text {, jika } D_{k l}<\underline{d}
$$

Sehingga matriks dominan discordance adalah

$$
g_{k l}=\left[\begin{array}{lllll}
- & 1 & 1 & 1 & 1 \\
0 & - & 1 & 1 & 1 \\
0 & 0 & - & 1 & 0 \\
0 & 0 & 1 & - & 0 \\
0 & 0 & 1 & 1 & -
\end{array}\right]
$$

7) Menentukan matriks dominan keseluruhan

Dengan menggunakkan persamaan (7) $E_{k l}=F_{k l} * G_{k l}$, maka matriks dominan keseluruhan adalah sebagai berikut: 
Berdasarkan matriks dominan keseluruhan $\mathrm{E}_{\mathrm{kl}}$, maka hasil akhir dari alternatif adalah sebagai berikut.

$$
\mathrm{E}_{\mathrm{kl}=}\left[\begin{array}{ccccc}
- & 1 & 1 & 1 & 1 \\
0 & - & 1 & 1 & 0 \\
0 & 0 & - & 1 & 0 \\
0 & 0 & 0 & - & 0 \\
0 & 0 & 1 & 1 & -
\end{array}\right]
$$

Berdasarkan hasil akhir yang diperoleh, maka didapat alternatif $\mathrm{A}_{1}$ dengan nilai $\mathrm{E}_{\mathrm{kl}}=4$, alternatif $A_{2}$ dengan nilai $E_{k l}=2$, alternatif $A_{3}$ dengan nilai $E_{k l}=1$, alternatif $A_{4}$ dengan nilai $\mathrm{E}_{\mathrm{kl}}=0$, alternatif $\mathrm{A}_{5}$ dengan nilai $\mathrm{E}_{\mathrm{kl}}=2$. Berdasarkan nilai $\mathrm{E}_{\mathrm{kl}}$ dari masing-masing alternatif, maka diperoleh pegawai terbaik dengan alternatif $A_{1}$ dengan nilai $E_{k l}$ nya adalah 4. Maka pegawai terbaik adalah Mulatua Siregar, SE. Hasil alternatif terbaik juga dapat dilihat pada tabel berikut:

Tabel 5. Hasil Alternatif Terbaik

\begin{tabular}{clllclcc}
\hline Alternatif & \multicolumn{1}{c}{ Nama Alternatif } & \multicolumn{3}{c}{ Nilai $\mathbf{E}_{\mathbf{k l}}$} & & Jumlah \\
\hline $\mathrm{A}_{1}$ & Mulatua Siregar, SE & - & 1 & 1 & 1 & 1 & 4 \\
$\mathrm{~A}_{2}$ & Mangaraja Tua Nababan, Spd, MM & 0 & - & 1 & 1 & 0 & 2 \\
$\mathrm{~A}_{3}$ & Missiadi,SH & 0 & 0 & - & 1 & 0 & 1 \\
$\mathrm{~A}_{4}$ & Lisna H Pohan & 0 & 0 & 0 & - & 0 & 0 \\
$\mathrm{~A}_{5}$ & Erni Sari & 0 & 0 & 1 & 1 & - & 2 \\
\hline
\end{tabular}

\section{Kesimpulan}

Berdasarkan uraian yang telah dipaparkan bab demi bab dari skripsi yang penulis buat, penulis menyimpulkan bahwa:

a) Metode ELECTRE dapat diterapkan dengan baik pada Sistem Pendukung Keputusan (SPK) dalam kasus pemilihan pegawai terbaik pada Kantor Camat Siantar Utara.

b) Sistem Pendukung Keputusan yang dibangun dengan menggunakan metode ELECTRE dapat melakukan perhitungan secara otomatis ketika pengguna menginputkan nilai kriteria sehingga dapat membantu mempercepat proses pengambilan keputusan dalam menentukan pegawai terbaik pada Kantor Camat Siantar Utara.

c) Hasil akhir yang diperoleh baik menggunakan perhitungan secara manual maupun secara komputerisasi menunjukkan hasil yang sama yaitu alternatif $A_{1}$ atas nama Mulatua Siregar, SE sebagai pegawai terbaik pada Kantor Camat Siantar Utara.

\section{Daftar Pustaka}

[1] S. Sundari et al., "Sistem Pendukung Keputusan Dengan Menggunakan Metode Electre Dalam Merekomendasikan Dosen Berprestasi Bidang Ilmu Komputer (Study Kasus di AMIK \& STIKOM Tunas Bangsa)," no. x, 2012.

[2] L. P. Purba, A. P. Windarto, and A. Wanto, "Faktor Terbesar Rendahnya Minat Ber-KB (Keluarga Berencana) Dengan Metode ELECTRE II,” pp. 369-374, 2018.

[3] F. Setiawan, F. Indriani, and Muliadi, "Implementasi Metode Electre Pada Sistem Pendukung Keputusan SNMPTN Jalur Undangan," Kumpul. J. Ilmu Komput., vol. 02, no. 02, pp. 88-101, 2015.

[4] S. Manurung, "Sistem Pendukung Keputusan Pemilihan Guru Dan Pegawai Terbaik Menggunakan Metode Moora," vol. 9, no. 1, pp. 701-706, 2018.

[5] D. R. Sari, A. P. Windarto, D. Hartama, and S. Solikhun, "Sistem Pendukung Keputusan untuk Rekomendasi Kelulusan Sidang Skripsi Menggunakan Metode 
AHP-TOPSIS," J. Teknol. dan Sist. Komput., vol. 6, no. 1, p. 1, 2018, doi: 10.14710/jtsiskom.6.1.2018.1-6.

[6] T. Imandasari and A. P. Windarto, "Sistem Pendukung Keputusan dalam Merekomendasikan Unit Terbaik di PDAM Tirta Lihou Menggunakan Metode Promethee," J. Teknol. dan Sist. Komput., vol. 5, no. 4, p. 159, 2017, doi: 10.14710/jtsiskom.5.4.2017.159-165.

[7] S. R. Ningsih, I. S. Damanik, I. Gunawan, and W. Saputra, "Electre Dalam Menentukan Penerima Program Indonesia Pintar (PIP) Melalui Kartu Indonesia Pintar (KIP) (Studi Kasus: SD Swasta Al-Washliyah Moho Kabupaten Simalungun)," vol. I, pp. 264-275, 2017. 